Metalorganic chemical vapor deposition growth and thermal stability of the AllnN/GaN high electron mobility transistor structure

This content has been downloaded from IOPscience. Please scroll down to see the full text. 2011 Semicond. Sci. Technol. 26085010 (http://iopscience.iop.org/0268-1242/26/8/085010)

View the table of contents for this issue, or go to the journal homepage for more

Download details:

IP Address: 139.179.14.46

This content was downloaded on 03/12/2013 at 22:53

Please note that terms and conditions apply. 


\title{
Metalorganic chemical vapor deposition growth and thermal stability of the AlInN/GaN high electron mobility transistor structure
}

\author{
Hongbo Yu ${ }^{1,3}$, Mustafa Ozturk ${ }^{1}$, Pakize Demirel ${ }^{1}$, Huseyin Cakmak ${ }^{1}$, \\ Basar Bolukbas $^{1}$, Deniz Caliskan ${ }^{1}$ and Ekmel Ozbay ${ }^{1,2}$ \\ ${ }^{1}$ Nanotechnology Research Center, Bilkent University, Bilkent, 06800 Ankara, Turkey \\ ${ }^{2}$ Department of Physics, and Department of Electrical and Electronics Engineering, Bilkent University, \\ Bilkent, 06800 Ankara, Turkey \\ E-mail: yuhongbows@gmail.com and hongboyu@bilkent.edu.tr
}

Received 21 September 2010, in final form 31 March 2011

Published 10 May 2011

Online at stacks.iop.org/SST/26/085010

\begin{abstract}
The $\mathrm{Al}_{x} \mathrm{In}_{1-x} \mathrm{~N}$ barrier high electron mobility transistor (HEMT) structure has been optimized with varied barrier composition and thickness grown by metalorganic chemical vapor deposition. After optimization, a transistor structure comprising a $7 \mathrm{~nm}$ thick nearly lattice-matched $\mathrm{Al}_{0.83} \mathrm{In}_{0.17} \mathrm{~N}$ barrier exhibits a sheet electron density of $2.0 \times 10^{13} \mathrm{~cm}^{-2}$ with a high electron mobility of $1540 \mathrm{~cm}^{2} \mathrm{~V}^{-1} \mathrm{~s}^{-1}$. An $\mathrm{Al}_{0.83} \mathrm{In}_{0.17} \mathrm{~N}$ barrier HEMT device with $1 \mu \mathrm{m}$ gate length provides a current density of $1.0 \mathrm{~A} \mathrm{~mm}^{-1}$ at $V_{\mathrm{GS}}=0 \mathrm{~V}$ and an extrinsic transconductance of $242 \mathrm{mS} \mathrm{mm}^{-1}$, which are remarkably improved compared to that of a conventional $\mathrm{Al}_{0.3} \mathrm{Ga}_{0.7} \mathrm{~N}$ barrier HEMT. To investigate the thermal stability of the HEMT epi-structures, post-growth annealing experiments up to $800{ }^{\circ} \mathrm{C}$ have been applied to $\mathrm{Al}_{0.83} \mathrm{In}_{0.17} \mathrm{~N}$ and $\mathrm{Al}_{0.3} \mathrm{Ga}_{0.7} \mathrm{~N}$ barrier heterostructures. As expected, the electrical properties of an $\mathrm{Al}_{0.83} \mathrm{In}_{0.17} \mathrm{~N}$ barrier HEMT structure showed less stability than that of an $\mathrm{Al}_{0.3} \mathrm{Ga}_{0.7} \mathrm{~N}$ barrier HEMT to the thermal annealing. The structural properties of $\mathrm{Al}_{0.83} \mathrm{In}_{0.17} \mathrm{~N} / \mathrm{GaN}$ also showed more evidence for decomposition than that of the $\mathrm{Al}_{0.3} \mathrm{Ga}_{0.7} \mathrm{~N} / \mathrm{GaN}$ structure after $800{ }^{\circ} \mathrm{C}$ post-annealing.
\end{abstract}

(Some figures in this article are in colour only in the electronic version)

\section{Introduction}

III-nitride-based semiconductor high electron mobility transistors (HEMTs) have attracted much attention for high frequency and high-power microwave applications, even in higher temperature environments [1]. In recent years, the HEMT epitaxial structures and devices using a thin $\mathrm{Al}_{x} \operatorname{In}_{1-x} \mathrm{~N}$ as barrier have been proposed, based on a theoretical calculation for significant improvements in drain currents and transconductances compared to those of $\mathrm{Al}_{x} \mathrm{Ga}_{1-x} \mathrm{~N}$ barrier HEMT [2-5]. One advantage of the $\mathrm{Al}_{x} \operatorname{In}_{1-x} \mathrm{~N}$ barrier is that it is lattice matched to a $\mathrm{GaN}$ buffer for an indium composition

\footnotetext{
3 Author to whom any correspondence should be addressed.
}

of approx. $17 \%$, which avoids the drawbacks of an in-plane strain formed in the $\mathrm{Al}_{x} \mathrm{Ga}_{1-x} \mathrm{~N} / \mathrm{GaN}$ heterostructures. At this indium composition, an $\mathrm{Al}_{0.83} \mathrm{In}_{0.17} \mathrm{~N} / \mathrm{GaN}$ heterostructure can generate a higher two-dimensional electron gas (2DEG) charge with a much thinner barrier layer than that in an $\mathrm{Al}_{0.3} \mathrm{Ga}_{0.7} \mathrm{~N} / \mathrm{GaN}$ heterostructure, due to the stronger spontaneous polarization effect and the larger band gap in the $\mathrm{Al}_{0.83} \operatorname{In}_{0.17} \mathrm{~N}$ barrier [2]. The decrease in barrier thickness is very important for the HEMT device to operate at a smallsignal high frequency by suppressing the short channel effects [6].

Although excellent device results have been reported from $\mathrm{Al}_{0.83} \mathrm{In}_{0.17} \mathrm{~N}$ barrier HEMT devices recently [7, 8], the thermal stability of the HEMT epitaxial structure has not been 
investigated extensively [9-11], which is a crucial property for electronic devices operated at high temperatures. Because the melt point of $\mathrm{InN}$ is around $1400 \mathrm{~K}$, which is much lower than that of $\mathrm{GaN}(\sim 2500 \mathrm{~K})$ and $\mathrm{AlN}(\sim 3000 \mathrm{~K})$ [12-14], the thermal stability of ternary $\mathrm{Al}_{x} \operatorname{In}_{1-x} \mathrm{~N}$ alloy is expected to be inferior to that of $\mathrm{Al}_{x} \mathrm{Ga}_{1-x} \mathrm{~N}$.

In this work, we studied the effects of the growth temperature and thickness of an $\mathrm{Al}_{x} \operatorname{In}_{1-x} \mathrm{~N}$ barrier on the electrical properties of HEMT structures. Furthermore, the thermal stability of the $\mathrm{Al}_{0.83} \mathrm{In}_{0.17} \mathrm{~N}$ barrier HEMT epitaxial structure was investigated as a function of the post-annealing temperature in comparison with the conventional $\mathrm{Al}_{0.3} \mathrm{Ga}_{0.7} \mathrm{~N}$ barrier HEMT structure.

\section{Experimental details}

The samples in the present study were all grown on a $c$-plane sapphire $\left(\mathrm{Al}_{2} \mathrm{O}_{3}\right)$ substrate in a low-pressure metalorganic chemical vapor deposition (MOCVD) reactor (AIX 200/4 RF$\mathrm{S})$. Standard trimethylgallium (TMGa), trimethylaluminum (TMAl), trimethylindium (TMIn) and ammonia $\left(\mathrm{NH}_{3}\right)$ were used as the precursors for $\mathrm{Ga}, \mathrm{Al}$, In and $\mathrm{N}$, respectively. For the $\mathrm{Al}_{x} \mathrm{In}_{1-x} \mathrm{~N} / \mathrm{GaN}$ heterostructures, the growth was initiated with the deposition of a $250 \mathrm{~nm}$ AlN buffer layer at $1150{ }^{\circ} \mathrm{C}$, followed by $\sim 1 \mu \mathrm{m}$ thick undoped $\mathrm{GaN}$ layer. This growth process results in a semi-insulating $\mathrm{GaN}$ film with high crystalline quality $[15,16]$. Therefore the electrical characterizations of the HEMT structures should not be influenced by parasitic conduction paths. A thin AlN interlayer was then grown on the GaN buffer in most cases in order to reduce alloy scattering. The wafer was cooled to temperatures ranging from 780 to $850{ }^{\circ} \mathrm{C}$ for the growth of the $\mathrm{Al}_{x} \mathrm{In}_{1-x} \mathrm{~N}$ barrier without any cap layer. The $\mathrm{Al}_{x} \operatorname{In}_{1-x} \mathrm{~N}$ barriers were grown using $26.5 \mu$ moles $\min ^{-1}$ TMAl, $72 \mu$ moles $\min ^{-1}$ of TMIn, $1.5 \mathrm{lpm}$ of $\mathrm{NH}_{3}$ and $8.0 \mathrm{lpm}$ of $\mathrm{N}_{2}$ carrier gas. The reactor pressure was kept at 50 mbar during $\mathrm{Al}_{x} \operatorname{In}_{1-x} \mathrm{~N}$ growths. The influence of the $\mathrm{Al}_{x} \operatorname{In}_{1-x} \mathrm{~N}$ barrier growth temperature and thickness on the electrical properties was investigated through two sets of samples. The schematic cross-sectional view of the $\mathrm{Al}_{x} \operatorname{In}_{1-x} \mathrm{~N}$ barrier HEMT and the scanning electron microscope (SEM) image from a selected epitaxial structure are shown in figures $1(a)$ and $(b)$, respectively. For comparison, a conventional $\mathrm{AlGaN} / \mathrm{GaN}$ HEMT structure was grown using the same MOCVD reactor, as described in the literature [16]. In this $\mathrm{AlGaN} / \mathrm{GaN}$ HEMT, the $\mathrm{Al}_{x} \operatorname{In}_{1-x} \mathrm{~N}$ barrier was replaced by a $25 \mathrm{~nm}$ thick $\mathrm{Al}_{0.3} \mathrm{Ga}_{0.7} \mathrm{~N}$, keeping all other layers and growth parameters identical. All of the epitaxial layers in the HEMT structures were unintentionally doped.

To investigate the thermal stability of the as-grown HEMT structures, the selected HEMT wafers were diced into $1 \times 1 \mathrm{~cm}^{2}$ squares for the post-annealing experiments. The diced samples were subjected to annealing at temperature ranging from 400 to $800{ }^{\circ} \mathrm{C}$ for 30 min under $\mathrm{N}_{2}$ ambient. The structural properties and indium compositions in $\mathrm{Al}_{x} \operatorname{In}_{1-x} \mathrm{~N}$ layers were characterized by high-resolution $\mathrm{x}$-ray diffraction (XRD) using a Rigaku-Smartlab system. For the electrical characterization, room temperature (300 K) and low

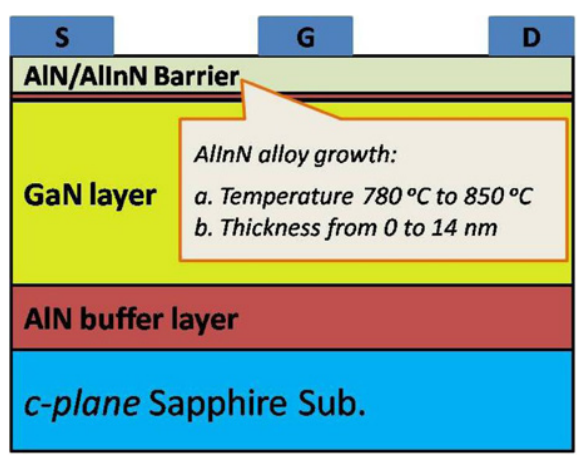

(a)

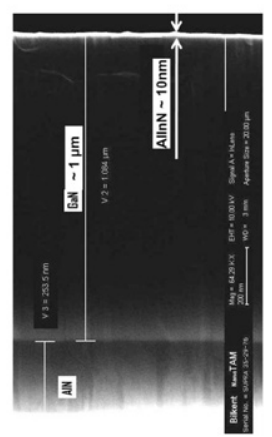

(b)
Figure 1. Schematic cross-sectional view of the AlInN barrier HEMT structure $(a)$ and a corresponding SEM image $(b)$.

temperature (77 K) Hall measurements using Van der Pauw geometry were carried out. Atomic force microscopy (AFM), Veeco di-CP II, was used to evaluate the sample surface morphology by the contact mode. SEM graphs were taken using a Raith e-LiNE electron beam lithography system.

\section{Results and discussion}

Figures 2(a) and (b) show the AFM images of the typical asgrown HEMT structures with $\mathrm{Al}_{0.83} \mathrm{In}_{0.17} \mathrm{~N}$ and $\mathrm{Al}_{0.3} \mathrm{Ga}_{0.7} \mathrm{~N}$ terminated surface. $\mathrm{Al}_{0.83} \mathrm{In}_{0.17} \mathrm{~N}$ and $\mathrm{Al}_{0.3} \mathrm{Ga}_{0.7} \mathrm{~N}$ barriers were grown at $830{ }^{\circ} \mathrm{C}$ and $1075{ }^{\circ} \mathrm{C}$, respectively. The two samples have a similar root mean square (RMS) surface roughness, which was measured as 0.38 and $0.32 \mathrm{~nm}$ over a $5 \times 5 \mu \mathrm{m}^{2}$ area, respectively. Although the $\mathrm{Al}_{0.83} \operatorname{In}_{0.17} \mathrm{~N}$ barrier is nearly lattice matched to the $\mathrm{GaN}$ buffer, the surface of the $\mathrm{Al}_{0.83} \operatorname{In}_{0.17} \mathrm{~N}$ shows the high density of small hillocks with a diameter of 20-50 nm and height of $\sim 1 \mathrm{~nm}$, which is significantly different to the well-developed stepflow $\mathrm{Al}_{0.3} \mathrm{Ga}_{0.7} \mathrm{~N}$ surfaces. It is possible that these small hillocks are associated with the low motion of the $\mathrm{Al}$ atom on the growing surface at a relatively low growth temperature and $\mathrm{N}_{2}$ ambient, or with indium segregation similar to the phenomenon observed in the thin $\mathrm{InGaN}$ layer on a $\mathrm{GaN}$ template [17].

Figures 3(a) and $(b)$ summarize the room temperature $(300 \mathrm{~K})$ electrical properties of the AlInN barrier HEMT as a function of the growth temperature and the thickness of the barrier. The 2DEG carrier density, mobility and sheet resistivity were measured by the Hall effect using van der Pauw geometry. The variations in growth temperature from 780 to $850{ }^{\circ} \mathrm{C}$ result in $\mathrm{Al}_{x} \operatorname{In}_{1-x} \mathrm{~N}$ layers with indium compositions decreasing from $\sim 25 \%$ to $\sim 12 \%$, which were determined by XRD characterizations and Vegard's law. As shown in figure $3(a)$, the $2 \mathrm{DEG}$ carrier density rises with the growth temperature as the polarization effect is enhanced with Al composition increasing in the $\mathrm{Al}_{x} \mathrm{In}_{1-x} \mathrm{~N}$ barrier. The highest mobility and lowest sheet resistivity are achieved simultaneously when the growth temperature is $830{ }^{\circ} \mathrm{C}$. At this point, the indium composition in the $\mathrm{Al}_{x} \operatorname{In}_{1-x} \mathrm{~N}$ barrier was measured as $\sim 17 \%$, which is nearly lattice matched to the GaN film. The effect of the AlInN thickness on the electrical 


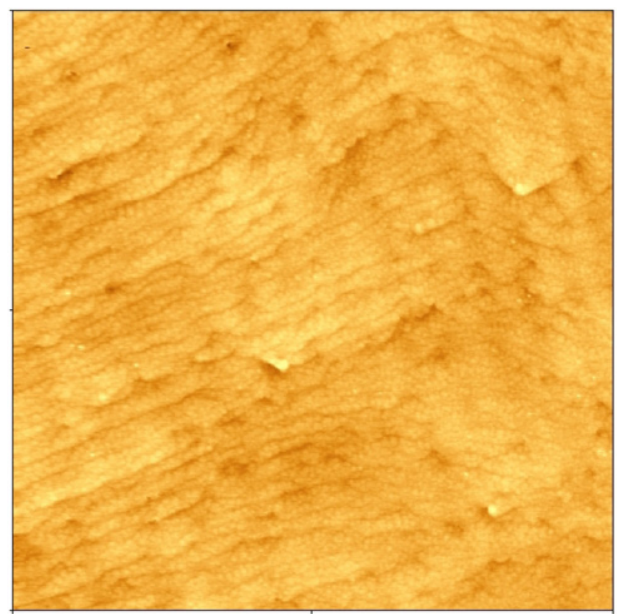

(a)

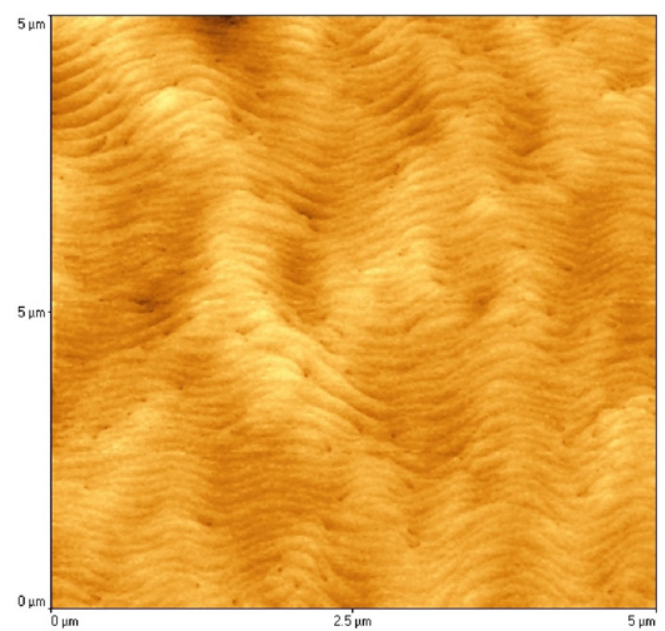

(b)

Figure 2. AFM images from $\mathrm{Al}_{0.83} \mathrm{In}_{0.17} \mathrm{~N}(a)$ and $\mathrm{Al}_{0.3} \mathrm{Ga}_{0.7} \mathrm{~N}(b)$ terminated HEMT structures $(5 \mu \mathrm{m} \times 5 \mu \mathrm{m})$.

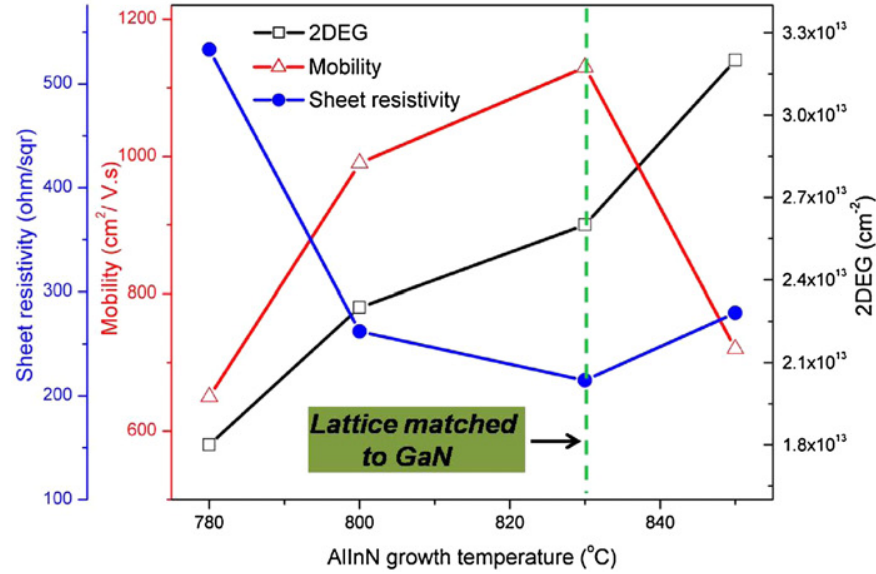

(a)

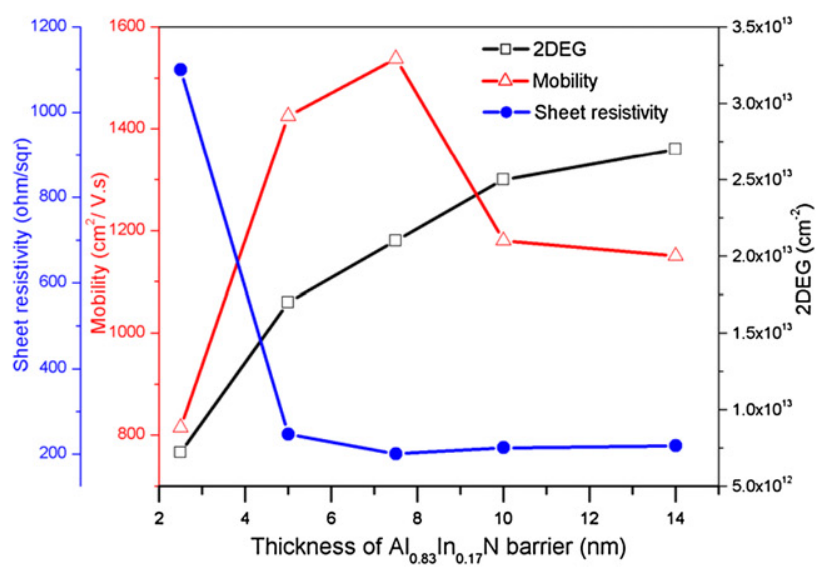

(b)

Figure 3. Electrical properties of the AlInN barrier HEMT as a function of the growth temperature $(a)$ and the thickness of the barrier $(b)$.

properties of the AlInN/AlN(1 nm)/GaN heterostructure was further investigated, keeping the indium composition as $\sim 17 \%$ in the AlInN barrier. As shown in figure $3(b)$, the sheet resistivity drops sharply with the $\mathrm{Al}_{0.83} \mathrm{In}_{0.17} \mathrm{~N}$ thickness increasing from 1 to $5 \mathrm{~nm}$. Then it keeps stable at about 200 to $210 \Omega \mathrm{sq}^{-1}$ as the $\mathrm{Al}_{0.83} \operatorname{In}_{0.17} \mathrm{~N}$ barrier increases further to $14 \mathrm{~nm}$. When the $\mathrm{Al}_{0.83} \mathrm{In}_{0.17} \mathrm{~N}$ thickness is $7 \mathrm{~nm}$, the highest electron mobility of $1540 \mathrm{~cm}^{2} \mathrm{~V}^{-1} \mathrm{~s}^{-1}\left(4260 \mathrm{~cm}^{2} \mathrm{~V}^{-1} \mathrm{~s}^{-1}\right.$ at $77 \mathrm{~K}$ ) is achieved with a $2 \mathrm{DEG}$ density of $\sim 2.0 \times 10^{13} \mathrm{~cm}^{-2}$. Our experimental results show that the optimized thickness of the $\mathrm{Al}_{0.83} \mathrm{In}_{0.17} \mathrm{~N}$ barrier for an HEMT structure is much lower than that of conventional $\mathrm{Al}_{0.3} \mathrm{Ga}_{0.7} \mathrm{~N} / \mathrm{GaN}$ HEMT, which is generally thicker than $20 \mathrm{~nm}$, in turn indicating potentially superior transistor performance for small-signal high frequency operation by alleviating the short channel effects [6].

Sample HEMT devices were fabricated from the epistructures of the $\mathrm{Al}_{0.83} \operatorname{In}_{0.17} \mathrm{~N}$ barrier and the conventional $\mathrm{Al}_{0.3} \mathrm{Ga}_{0.7} \mathrm{~N}$ barrier HEMTs. Ti/Al/Ni/Au (20/200/40/ $50 \mathrm{~nm}$ ) was deposited for the source and drain Ohmic contacts that were annealed at $850{ }^{\circ} \mathrm{C}$ for $30 \mathrm{~s}$ under nitrogen ambient.
The Ni/Au (40/100 nm) Schottky gates were then metalized. The gate length $\left(L_{\mathrm{G}}\right)$, gate width $\left(W_{\mathrm{G}}\right)$, distance between the source and drain $\left(L_{\mathrm{SD}}\right)$, and distance between the source and gate $\left(L_{\mathrm{SG}}\right)$ of the HEMT devices were $1,250,3$ and $1 \mu \mathrm{m}$, respectively. Figure 4(a) compares the direct current (dc) current-voltage $\left(I_{d}-V_{d}\right)$ output characteristics of the two kinds of devices with the same size. As shown in this figure, both of the two devices operate with good pinch-off characteristics due to the high resistance of the $\mathrm{GaN}$ buffer. When the gate bias was $0 \mathrm{~V}$, the maximum drain current densities were measured as $\sim 1.0$ and $\sim 0.6 \mathrm{~A} \mathrm{~mm}^{-1}$ for the $\mathrm{Al}_{0.83} \operatorname{In}_{0.17} \mathrm{~N}$ barrier HEMT (black square) and $\mathrm{Al}_{0.3} \mathrm{Ga}_{0.7} \mathrm{~N}$ barrier HEMT (red square frame), respectively. The remarkable higher output conductance from $\mathrm{Al}_{0.83} \mathrm{In}_{0.17} \mathrm{~N}$ barrier HEMT was attributed to the lower sheet resistivity of the epi-structure, resulting from the increase in the $2 \mathrm{DEG}$ carrier density. At the large drain biases and high current levels, negative differential resistance can be observed in both of the devices, which might be caused by the low thermal conductivity of the sapphire substrate. Moreover, the peak extrinsic transconductance was measured as about 157 and $242 \mathrm{mS} \mathrm{mm}^{-1}$ for the 


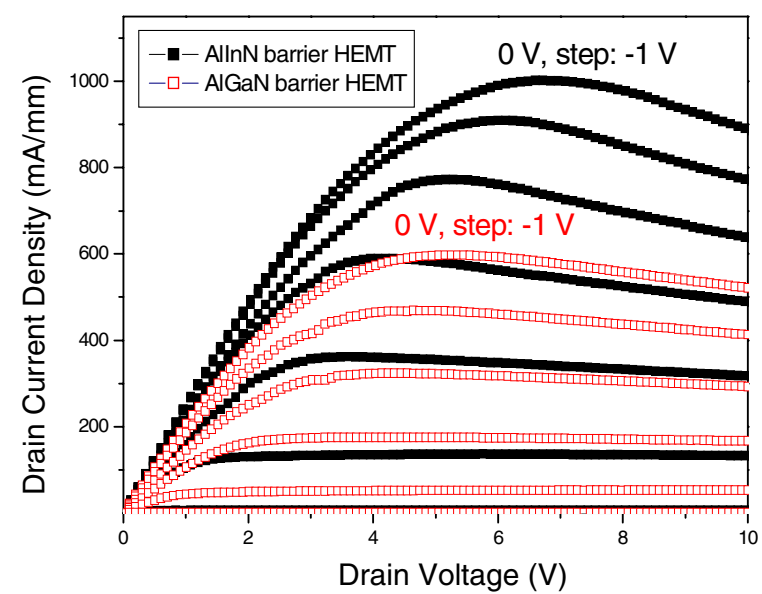

(a)

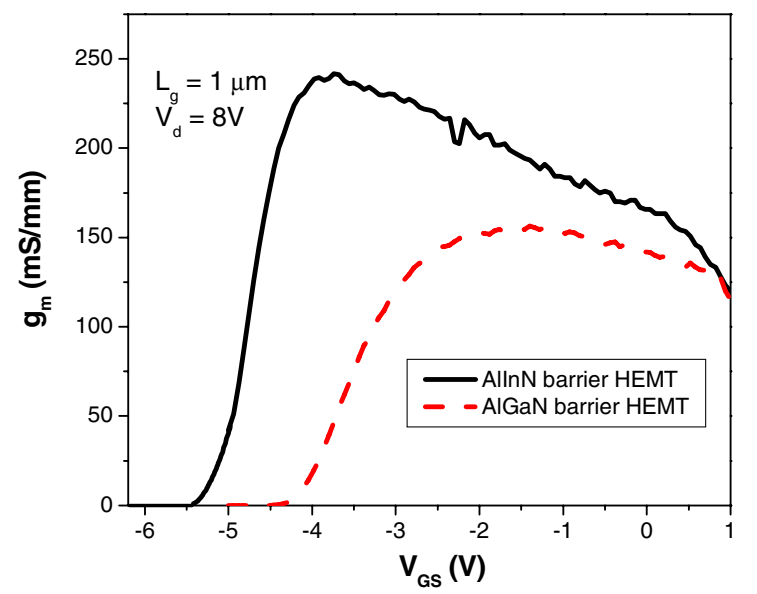

(b)

Figure 4. DC-IV output characteristics (a) and extrinsic transconductance $(b)$ of the conventional $\mathrm{Al}_{0.3} \mathrm{Ga}_{0.7} \mathrm{~N}$ barrier HEMT and $\mathrm{Al}_{0.83} \mathrm{In}_{0.17} \mathrm{~N}$ barrier HEMT.

Table 1. List of the AlGaN and AlInN barrier HEMT epi-structures with main structural parameters characterization results: 300 and $77 \mathrm{~K}$ Hall-effect measurements as a function of the post-annealing temperature ranging from 400 to $800{ }^{\circ} \mathrm{C}$.

\begin{tabular}{|c|c|c|c|c|c|c|c|}
\hline \multirow[b]{2}{*}{ Sample } & \multirow[b]{2}{*}{ Barrier thickness } & \multirow[b]{2}{*}{ AlN spacer } & \multirow{2}{*}{$\begin{array}{l}\text { Annealing } \\
\text { temperature }\left({ }^{\circ} \mathrm{C}\right)\end{array}$} & \multicolumn{2}{|c|}{$\begin{array}{c}\text { Mobility } \\
\left(\mathrm{cm}^{2} \mathrm{~V}^{-1} \mathrm{~s}^{-1}\right)\end{array}$} & \multicolumn{2}{|c|}{$\begin{array}{c}\text { Sheet carrier } \\
\text { density } \\
\left(\times 10^{13} \mathrm{~cm}^{-2}\right)\end{array}$} \\
\hline & & & & $300 \mathrm{~K}$ & $77 \mathrm{~K}$ & $300 \mathrm{~K}$ & $77 \mathrm{~K}$ \\
\hline \multirow[t]{6}{*}{$\mathrm{Al}_{0.17} \mathrm{In}_{0.83} \mathrm{~N}$ barrier HEMT } & \multirow[t]{6}{*}{$10 \mathrm{~nm}$} & \multirow[t]{6}{*}{$1.0 \mathrm{~nm}$} & As-grown & 1130 & 3196 & 2.7 & 2.4 \\
\hline & & & 400 & 890 & 2570 & 3.1 & 2.8 \\
\hline & & & 500 & 695 & 1762 & 3.1 & 2.6 \\
\hline & & & 600 & 615 & 1269 & 3.2 & 2.9 \\
\hline & & & 700 & 319 & 430 & 3.4 & 2.9 \\
\hline & & & 800 & 104 & 70 & 0.39 & 0.078 \\
\hline \multirow[t]{6}{*}{$\mathrm{Al}_{0.3} \mathrm{Ga}_{0.7} \mathrm{~N}$ barrier HEMT } & \multirow[t]{6}{*}{$25 \mathrm{~nm}$} & \multirow[t]{6}{*}{$1.0 \mathrm{~nm}$} & As-grown & 1700 & 13360 & 1.0 & 1.0 \\
\hline & & & 400 & 1710 & 13200 & 1.0 & 1.0 \\
\hline & & & 500 & 1700 & 12740 & 1.0 & 1.0 \\
\hline & & & 600 & 1680 & 11300 & 1.1 & 1.1 \\
\hline & & & 700 & 1686 & 9200 & 1.1 & 1.0 \\
\hline & & & 800 & 1035 & 4200 & 1.0 & 1.0 \\
\hline
\end{tabular}

$\mathrm{Al}_{0.3} \mathrm{Ga}_{0.7} \mathrm{~N}$ and $\mathrm{Al}_{0.83} \mathrm{In}_{0.17} \mathrm{~N}$ barrier HEMTs, respectively, under $V_{\mathrm{DS}}=8 \mathrm{~V}$. The combination of high current density and high transconductance in a single $\mathrm{Al}_{0.83} \mathrm{In}_{0.17} \mathrm{~N}$ barrier HEMT is promising especially for high frequency and high-power applications.

The properties of the III-nitride-based HEMT are sensitive to the post-annealing conditions, such as annealing temperature and time [18-20]. Table 1 summarizes the $\mathrm{Al}_{0.17} \mathrm{In}_{0.83} \mathrm{~N}$ and $\mathrm{Al}_{0.3} \mathrm{Ga}_{0.7} \mathrm{~N}$ barrier HEMT structural parameters and the electrical properties as a function of the post-annealing temperatures. For the $\mathrm{Al}_{0.83} \mathrm{In}_{0.17} \mathrm{~N}$ barrier HEMT, sheet carrier density increases remarkably from 2.7 to $3.4 \times 10^{13} \mathrm{~cm}^{-2}$ after the samples are annealed at temperatures ranging from $400{ }^{\circ} \mathrm{C}$ to $700{ }^{\circ} \mathrm{C}$. In another report, NieChuan Chen et al [18] attributes a similar phenomenon of the AlGaN barrier HEMT to the surface states enhancement caused by thermal annealing. Because the III-nitride device was normally grown on foreign substrates, such as sapphire, $\mathrm{SiC}$ and $\mathrm{Si}$, there exists high density of threading or point defects in the epi-structures. Therefore, the growth conditions significantly influence the density of defects and electrical properties of the HEMT structure. In our experiments, the sheet carrier density of the $\mathrm{Al}_{0.3} \mathrm{Ga}_{0.7} \mathrm{~N}$ barrier HEMT remains nearly constant at about $1.0-1.1 \times 10^{13} \mathrm{~cm}^{-2}$ through the studied annealing temperature ranging from $400{ }^{\circ} \mathrm{C}$ to $800{ }^{\circ} \mathrm{C}$, which is possibly due to the improvement of crystal and surface quality of the epi-structure by applying high temperature AlN template $[15,16]$, while the enhancement of sheet carrier density after thermal annealing in the $\mathrm{Al}_{0.83} \mathrm{In}_{0.17} \mathrm{~N}$ barrier HEMT is attributed to the relative low crystal quality and thermal stability under high temperature. In addition, for the $\mathrm{Al}_{0.83} \operatorname{In}_{0.17} \mathrm{~N}$ barrier HEMT, the sheet carrier density at $77 \mathrm{~K}$ is remarkably lower than that at $300 \mathrm{~K}$, while the sheet carrier density nearly does not change for the $\mathrm{Al}_{0.3} \mathrm{Ga}_{0.7} \mathrm{~N}$ barrier HEMT at $77 \mathrm{~K}$ and $300 \mathrm{~K}$. It is due to the relatively higher defect density in $\mathrm{Al}_{0.83} \mathrm{In}_{0.17} \mathrm{~N} / \mathrm{GaN}$ heterostructure and the electron defect trapping effect at low temperature. When the annealing temperature further increased to $800^{\circ} \mathrm{C}$, the room temperature sheet carrier density and mobility sharply dropped to $0.39 \times 10^{13} \mathrm{~cm}^{-2}$ and 


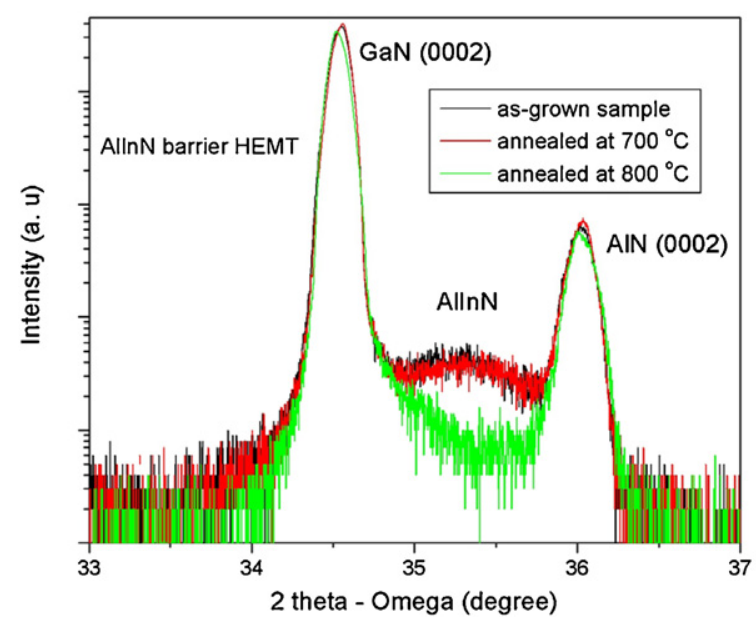

(a)

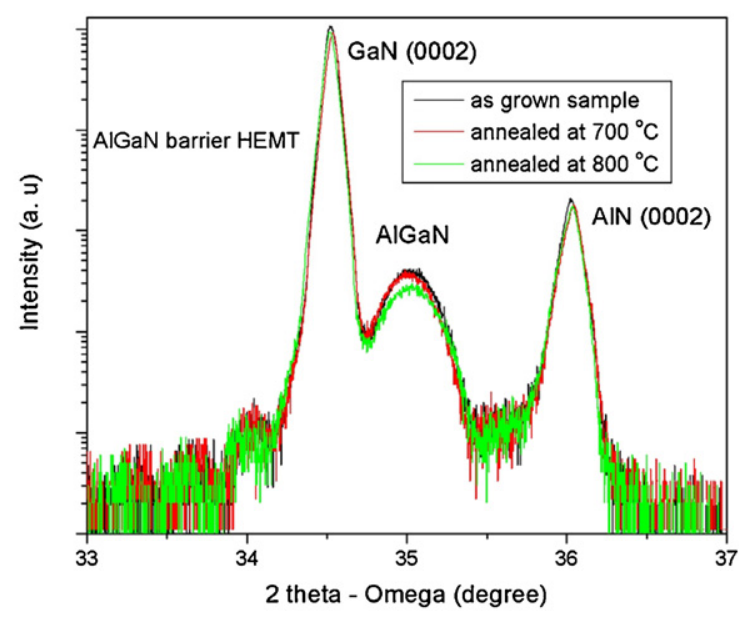

(b)

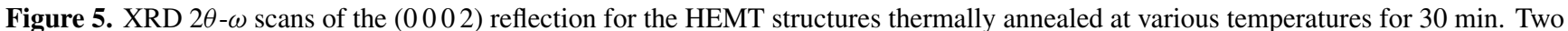
kinds of the HEMT structures are shown with $(a) \mathrm{Al}_{0.83} \mathrm{In}_{0.17} \mathrm{~N}$ barrier and $(b) \mathrm{Al}_{0.3} \mathrm{Ga}_{0.7} \mathrm{~N}$ barrier.

$104 \mathrm{~cm}^{2} \mathrm{~V}^{-1} \mathrm{~s}^{-1}$, respectively. This phenomenon is caused by the decomposition of the $\mathrm{Al}_{0.83} \mathrm{In}_{0.17} \mathrm{~N}$ barrier and collapse of the $\mathrm{Al}_{0.83} \mathrm{In}_{0.17} \mathrm{~N} / \mathrm{AlN} / \mathrm{GaN}$ heterostructure, as confirmed in the following experiments. In contrast, the electrical properties of the $\mathrm{Al}_{0.3} \mathrm{Ga}_{0.7} \mathrm{~N}$ barrier HEMT show more resistance to the post-growth thermal annealing. The room temperature mobility of the 2DEG was kept at $\sim 1700 \mathrm{~cm}^{2}$ $\mathrm{V}^{-1} \mathrm{~s}^{-1}$ until the annealing temperature up to $700^{\circ} \mathrm{C}$. Then, it reduced to $1035 \mathrm{~cm}^{2} \mathrm{~V}^{-1} \mathrm{~s}^{-1}$ with the annealing temperature further increasing to $800{ }^{\circ} \mathrm{C}$.

Two observations are apparent from the examination of table 1. Firstly, the $\mathrm{Al}_{0.83} \mathrm{In}_{0.17} \mathrm{~N}$ barrier HEMT structure is less resistive to the increase in thermal annealing temperature than the $\mathrm{Al}_{0.3} \mathrm{Ga}_{0.7} \mathrm{~N}$ barrier HEMT due to the indium combination and lower MOCVD growth temperature. Second, the mobility is more sensitive to the increase in annealing temperature than the sheet carrier density for the $\mathrm{Al}_{0.3} \mathrm{Ga}_{0.7} \mathrm{~N}$ HEMT structure.

Shown in figure 5 for each of the HEMT structures are a series of XRD $2 \theta-\omega$ scans of the GaN $\left(\begin{array}{llll}0 & 0 & 0 & 2\end{array}\right)$ reflection. For both of the HEMT samples shown in figures $5(a)$ and $(b)$ neither the barrier peak intensities nor the line widths change significantly after annealing up to $700{ }^{\circ} \mathrm{C}$, in turn indicating that the $\mathrm{Al}_{0.83} \mathrm{In}_{0.17} \mathrm{~N} / \mathrm{GaN}$ and $\mathrm{Al}_{0.3} \mathrm{Ga}_{0.7} \mathrm{~N} / \mathrm{GaN}$ structural integrities are maintained up to this annealing temperature. When the XRD peaks of the samples are examined after annealing at $800{ }^{\circ} \mathrm{C}$, it shows almost no XRD peak for the $\mathrm{Al}_{0.83} \mathrm{In}_{0.17} \mathrm{~N}$ barrier, while the $\mathrm{Al}_{0.3} \mathrm{Ga}_{0.7} \mathrm{~N}$ HEMT sample keeps a $75 \%$ barrier intensity of the original. A stronger decrease in the XRD intensity of the $\mathrm{Al}_{0.83} \mathrm{In}_{0.17} \mathrm{~N}$ barrier compared to that of the $\mathrm{Al}_{0.3} \mathrm{Ga}_{0.7} \mathrm{~N}$ barrier sample is observed, indicating the relatively low structural thermal stability of the $\mathrm{Al}_{0.83} \mathrm{In}_{0.17} \mathrm{~N} / \mathrm{GaN}$ heterostructure.

The AFM images of the annealed HEMT structures are shown in figure 6. The $\mathrm{Al}_{0.83} \mathrm{In}_{0.17} \mathrm{~N}$ barrier samples annealed at 700 and $800{ }^{\circ} \mathrm{C}$ are shown in figures $6(a)$ and $(b)$, respectively. The $\mathrm{Al}_{0.3} \mathrm{Ga}_{0.7} \mathrm{~N}$ barrier samples annealed at 700 and $800{ }^{\circ} \mathrm{C}$ are shown in figures $6(c)$ and $(d)$, respectively.
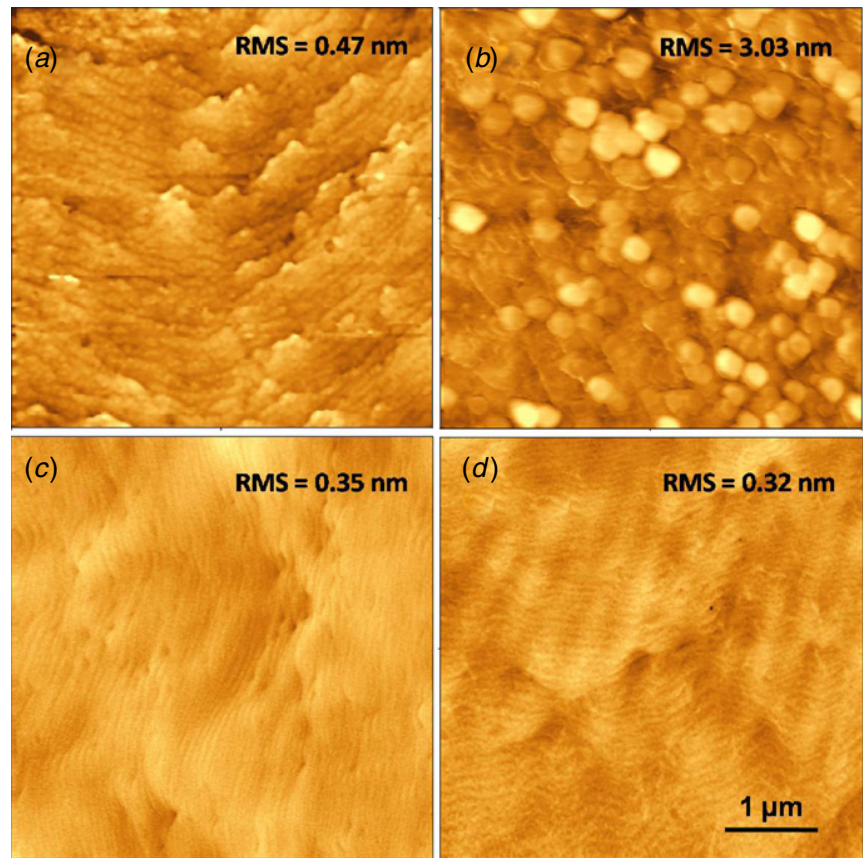

Figure 6. AFM images of HEMT epitaxial structures after thermal annealing: $(a)$ and $(b) \mathrm{Al}_{0.83} \mathrm{In}_{0.17} \mathrm{~N}$ barrier HEMT annealed at 700 and $800{ }^{\circ} \mathrm{C}$, respectively; $(c)$ and $(d) \mathrm{Al}_{0.3} \mathrm{Ga}_{0.7} \mathrm{~N}$ barrier HEMT annealed at 700 and $800{ }^{\circ} \mathrm{C}$, respectively.

When the anneal temperature is lower than $700{ }^{\circ} \mathrm{C}$, both of the HEMT epitaxial structures do not show remarkable change in the surface morphologies (not shown here). For the $\mathrm{Al}_{0.83} \operatorname{In}_{0.17} \mathrm{~N}$ barrier HEMT, the measured RMS roughness in the as-grown sample is $0.32 \mathrm{~nm}$, as shown in figure $2(a)$, and increased to $0.47 \mathrm{~nm}$ as shown in figure $6(a)$. Note that when the annealing temperature is $800{ }^{\circ} \mathrm{C}$, the surface of the $\mathrm{Al}_{0.83} \mathrm{In}_{0.17} \mathrm{~N}$ barrier suffered from some decomposition, which is characterized by the high density of truncated cones. The measured RMS roughness increased remarkably to $3.03 \mathrm{~nm}$ as shown in figure $6(b)$. The average height of the cone is approx. $30 \mathrm{~nm}$, which is much larger than the 
as-grown thickness of the $\mathrm{Al}_{0.83} \operatorname{In}_{0.17} \mathrm{~N}$ barrier. In contrast, the atomic smooth step-flow surface was retained with an annealing temperature up to $800{ }^{\circ} \mathrm{C}$ for the $\mathrm{Al}_{0.3} \mathrm{Ga}_{0.7} \mathrm{~N}$ barrier HEMT structure. The measured RMS roughness was marked in each of the AFM image. The AFM experimental results show that, in comparison to the $\mathrm{Al}_{0.83} \mathrm{In}_{0.17} \mathrm{~N} / \mathrm{GaN}$ heterostructure, the $\mathrm{Al}_{0.3} \mathrm{Ga}_{0.7} \mathrm{~N} / \mathrm{GaN}$ shows more thermal stability. The $\mathrm{Al}_{0.83} \mathrm{In}_{0.17} \mathrm{~N} / \mathrm{GaN}$ heterostructure collapses after thermal annealing at $800{ }^{\circ} \mathrm{C}$, which is rather consistent with the XRD characterizations.

In summary, we optimized AlInN barrier heterostructures with varied barrier composition and thickness grown by MOCVD. The optimized HEMT structure comprising a $7 \mathrm{~nm}$ thick nearly lattice-matched AlInN barrier exhibits a sheet electron density of $2.0 \times 10^{13} \mathrm{~cm}^{-2}$ and an electron mobility of $1540 \mathrm{~cm}^{2} \mathrm{~V}^{-1} \mathrm{~s}^{-1}$. AlInN barrier HEMT devices fabricated with a $1 \mu \mathrm{m}$ gate length provide a current density of $1.0 \mathrm{~A} \mathrm{~mm}^{-1}$ at $V_{\mathrm{GS}}=0 \mathrm{~V}$ and an extrinsic transconductance of $242 \mathrm{mS} \mathrm{mm}^{-1}$, which are remarkably improved compared to that of the conventional $\mathrm{Al}_{0.3} \mathrm{Ga}_{0.7} \mathrm{~N}$ barrier HEMT. The effects of thermal annealing on the HEMT structures have been investigated by AFM, Hall effect measurement and xray diffraction. The experimental results suggest that both the electrical and structural properties of an $\mathrm{Al}_{0.83} \mathrm{In}_{0.17} \mathrm{~N}$ barrier HEMT structure have less stability than those of the $\mathrm{Al}_{0.3} \mathrm{Ga}_{0.7} \mathrm{~N}$ barrier HEMT to the thermal annealing.

\section{References}

[1] Morkoç H 2008 Handbook of Nitride Semiconductors and Devices Vol I-III (New York: Wiley)
[2] Kuzmik J 2001 IEEE Electron Device Lett. 22510

[3] Kuzmík J 2002 Semicond. Sci. Technol. 17540

[4] Dadgar A, Schulze F, Bläsing J, Diez A, Krost A, Neuburger M, Kohn E, Daumiller I and Kunze M 2004 Appl. Phys. Lett. 855400

[5] Gonschorek M, Carlin J-F, Feltin E, Py M A and Grandjean N 2006 Appl. Phys. Lett. 89062106

[6] Jessen G, Fitch R, Gillespie J, Via G, Crespo A, Langley D, Denninghoff D, Trejo M and Heller E 2007 IEEE Trans. Electron Devices $\mathbf{5 4} 2589$

[7] Sun H, Alt A R, Benedickter H, Feltin E, Carlin J, Gonschorek M, Grandjean N and Bolognesi C R 2010 IEEE Electron Device Lett. 31293

[8] Chabak K D et al 2010 IEEE Electron Device Lett. 31561

[9] Medjdoub F, Alomari M, Carlin J-F, Gonschorek M, Feltin E, Py M A, Grandjean N and Kohn E 2007 ISDRS 2007, College Park, MD, USA

[10] Medjdoub F, Carlin J F, Gaquière C, Grandjean N and Kohn E 2008 Open Electr. Electron. Eng. J. 21

[11] Brice H R, Sadler T C, Kappers M J and Oliver R A 2010 J. Cryst. Growth 3121800

[12] MacChesney J B, Bridenbaugh P M and O'Connor P B 1970 Mater. Res. Bull. 5783

[13] Harafuji K, Tsuchiya T and Kawamura K 2004 J. Appl. Phys. 962501

[14] Porowski S 1997 Mater. Sci. Eng. B 44407

[15] Yu H, Ozturk M K, Ozcelik S and Ozbay E 2006 J. Cryst. Growth 293273

[16] Yu H, Caliskan D and Ozbay E 2006 J. Appl. Phys. 100033501

[17] Singh R, Doppalapudi D, Moustakas T D and Romano L T 1997 Appl. Phys. Lett. 701089

[18] Chen N-C, Tseng C-Y and Lin H-T 2009 J. Cryst. Growth 311859

[19] Kim H, Lee J and Lu W 2005 Phys. Status Solidi a 202841

[20] Lee J, Liu D, Kim H and Lu W 2004 Appl. Phys. Lett. 852631 